\title{
An Electrochemical Investigation of Corrosion Behavior of 316L Austenitic Stainless Steel Reinforcement in Concrete Exposed to Acidic Environment
}

\author{
Chunjiao Chen ${ }^{1}$, Jingwu Zuo ${ }^{2, *}$, Yingjie Wang ${ }^{3}$ \\ ${ }^{1}$ School of Architecture,South China University of Technology, Guangzhou 510641, China \\ ${ }^{2}$ School of Engineering Technology, Beijing Normal University, Zhuhai, 519087, China \\ ${ }^{3}$ China Water Resources Pearl River Planning, Survey \\ \&DesigningCo.,Ltd. Guangzhou, 510610, China \\ "E-mail: zuojingwubnu@ 163.com
}

doi: $10.20964 / 2020.06 .15$

Received: 7 October 2019/ Accepted: 22 November 2019 / Published: 10 May 2020

\begin{abstract}
Steel reinforced concrete has the potential to withstand a variety of adverse environmental conditions. Nowadays, corrosion in reinforced concrete is highly regarded due to the durability of the structures. In this research, concrete cubes containing $50 \mathrm{wt} . \%$ Limestone and reinforced with $316 \mathrm{~L}$ austenitic and 2304 duplex stainless steels were subjected to study on corrosion behavior in $0.5 \mathrm{M} \mathrm{H}_{2} \mathrm{SO}_{4}$ solution using open-circuit potential and electrochemical impedance spectroscopy techniques. The corrosion current density of the $316 \mathrm{~L}$ austenitic and 2304 duplex steels were 0.052 and $0.063 \mu \mathrm{A} / \mathrm{cm}^{2}$, respectively, which determined by potentiodynamic polarization diagrams. These results show that both steel reinforced concretes remained completely in the passive state during the test which indicates their good corrosion resistance in the acidic environment. Niquist diagram of the 316L austenitic stainless steel rebar indicates only an incomplete capacitive semi-circle, indicating the formation of a passive layer with a high protective property.An inductive behavior at high frequency was observed for 2304 duplex steel. Scanning electron microscope image indicates that 316L austenitic stainless steel surface was without evidence of pores/defects and unevenness which can reduce the influence of aggressive ions and moisture on the surface.
\end{abstract}

Keywords: Stainless steel reinforced concrete; Corrosion resistance; 316L austenitic stainless steel; Electrochemical impedance spectroscopy; Corrosive environment

\section{$\underline{\text { FULL TEXT }}$}

(C) 2020 The Authors. Published by ESG (www.electrochemsci.org). This article is an open access article distributed under the terms and conditions of the Creative Commons Attribution license (http://creativecommons.org/licenses/by/4.0/). 